\title{
New Wave of Democratization: The Case of Tunisian and Egyptian Revolutions
}

\author{
Mohd Irwan Syazli Saidin ${ }^{1}$, Wan Kamal Mujani ${ }^{2}$ and Azyati Azhani Mazuki ${ }^{2}$ \\ ${ }^{1}$ Centre for History, Politics and Strategy, Faculty of Social Science and Humanities \\ Universiti Kebangsaan Malaysia, 43600 Bangi,Selangor, Malaysia. \\ ${ }^{2}$ Department of Arabic Studies and Islamic Civilization, Faculty of Islamic Studies \\ Universiti Kebangsaan Malaysia, 43600 Bangi,Selangor, Malaysia. \\ irwansyazli@yahoo.com,_inamal@yahoo.com \& azhani1417@yahoo.com
}

\begin{abstract}
In recent years, the world has witnessed a dramatic change in Middle Eastern political landscape with the collapse of several long-serving dictators from Tunisia, Egypt, Yemen and Libya. They were the former presidents of these countries who, in the unfolding of history, had been ousted by their own people from a massive revolution known as the Arab Spring. This event has raised a question among political scientists; whether it is a sign of the coming wave or the new wave of democratization. Therefore, this dissertation aims to identify the extent of the correlation between the countries involved in the Arab Spring, specifically the Tunisian and Egyptian revolutions, with the new wave of democratization. By revisiting the previous wave of democratization, this article will view closely the extent to which the factors that contributed to the Tunisian Jasmine Revolution and the Egyptian 25 January Revolution could serve as the new wave of democratization..
\end{abstract}

Keywords-Arab spring; democratization, democratic transition, new social media

\section{INTRODUCTION}

The political ferment unleashed by the Egyptian and Tunisian Revolutions in 2011 has been an unprecedented one. Never before had a popular protest brought down an autocratic regime in the Arab world and none had anticipated the speed at which such deeply entrenched regimes might be ousted. The quick succession of the Jasmine Revolution and the fall of Mubarak regime in Egypt raised the hope among political activists that a contagious wave of revolution might soon usher in political change, thus beginning the process of democratic transition across the region [1]. It seems that these 21 st century revolutions mark the sign of new wave of democratization along with new elements and their unique characteristics.

\section{THE NEW WAVE OF DEMOCRATIZATION: COMPARISON OF THE TUNISIAN AND EGYPTIAN REVOLUTIONS}

Since this article adopts two different case studies, it is vital to look into some comparisons in order to find out any similarities or differences which can be used to understand the phenomena of the Arab Spring and their relation with the so called the 'new wave of democratization'. By looking at the factors which led to the revolution and regime change, this article has found that both Tunisian and Egyptian revolutions shared a number of common reasons why the mass protest was carried out across the countries against their regimes. A number of factors have been selected under five main themes namely economics development, political legitimacy, social demography, Islamism and the advance of new social media. The connection between factors that contributed in the Arab Spring and with the previous wave of democratization is vitally important to justify the Tunisian and Egyptian revolutions as one of the waves of democratic transition.

Firstly, from the economic perspectives, both countries had experienced bad economic conditions and weak management from the state for several years, prior to the revolution which led to the problem of inflation, rising commodity prices, high rates of unemployment, poverty and other social problems. Unemployment itself has created many problems especially among young graduates and youth when they desperately fall back to any job just for surviving. Inevitably, this factor seemed aligned with Lipset's idea about the importance of the economic development as a prerequisite of a democratic state and means to promote the process of democratization. Besides, Hungtinton had also emphasized the factor of social and economic development responsible for the first wave of democratization [2].

Secondly, from the political dimension, both Mubarak and Ben Ali regime had used to practice the dictatorshipstyle with political regression; in these countries the opposition parties were so weak and there was a slim chance for them to challenge the ruling parties; the widespread of human right abuse-mainly from police and security apparatus; and strict restriction on freedom of speech and press implemented through state's emergency laws. These problems of political legitimacy, as Huntington has explained in his idea of 'third democratization wave', played an important role which led to the collapse of the USSR and the authoritarian regime during the phase of the second and third waves of world democratization. The failure and ineffectiveness of Mubarak and Ben Ali regime in addressing political problems and human rights issue as stated above, served as a clear example to support what Lipset had mentioned 50 years ago about the significance of political legitimacy to sustain democracy [3].

Thirdly, it was such a coincidence when both revolutions were driven by a group of young people, mainly aged 20-30 
who were frustrated with unemployment, socioeconomic problems and their failed political institutions, and they were supported by the majority of their nations from different backgrounds. This demographic factor was considered as one of the reasons why the protests managed to hold for two or three weeks continuously even when they had faced a heavy 'counter-protest' from the regime. This national unity practiced by the Egyptians and Tunisians during the revolution was simply and solely parallel with Rustow's 'dynamic model' for democratic transition when he mentioned the importance of background condition- the national unity as the first phase that every country must have before achieving democratic transition [4].

Next, in both the Tunisian Jasmine Revolution and Egyptian 25 January Revolution, although the majority of the populations are Muslims, it seemed that Islamists, whether from Ennahda or Muslim Brotherhood did not play a major role on the eve of the revolution, as the protesters demanded mainly social and political justice and the immediate resignation of Ben Ali and Mubarak. There was no 'Islamic Revolution' applied to these events as the protesters came from diverse backgrounds- the trade unionists, liberalists, political activists, students, youths and middle class citizens. Some Islamist parties may have benefited from the Arab Spring, as in the aftermath of both revolutions, but they did not inspire the protest and were hesitated to join until regime change was close to a real possibility [5]. Although Alfred Stepan, through his idea of 'twin tolerations' arguably agreed that religion can contribute to the continuity of democratic transition, it seems that Islamism did not motivate the revolution [6]. The Islamists, however, played the game cleverly when they 'hijacked' the revolts through a new election after the regime collapsed. Regarding this, it is considered something new as it never happened during the first, second and the third democratic waves.

Finally, one other factor that must be highlighted to explain the timing and success of the popular uprisings in both Tunisia and Egypt is the role of the new social media. Facebook, Twitter, YouTube and Blogs provided the means for alternative press besides coordinating and synchronizing the actions of thousands of people, thereby making mass gathering become possible even in the absence of any single leader, political ideology and formal organizational infrastructure. Interestingly, new social media served as new tool to generate political awareness among citizens more quickly and frequently, thus making the nation solidarity against corrupt leadership become reality. Most importantly, as stressed by Bellin, it was the spontaneity of new social media which enabled Egyptians and Tunisians to circulate information rapidly besides creating a chance to escape the control and repression of the autocratic regime [7]. It has been 20 years ago, when Huntington used to associate the significance of demonstration effects enhanced by global communication with one of the changes involving the third wave of democratization. However, what he meant by that is not the latest global communication trend or the role of new social media since that time the Internet was still underway and was very rare among the world population. Nevertheless, media and communication were still considered as part of the democratic transition waves.

\section{ElEMENTS That Distinguish the TUNiSian Jasmine REVOLUTION AND EGYPTIAN 25 JANUARY REVOLUTION}

Despite the common factors and elements in democratic transition involved in the Egyptian and Tunisian Uprisings as discussed above, this article strongly argues that the Tunisian Jasmine Revolution and the Egyptian Uprising are unique in many ways, rendering it different from the previous waves of democratization especially from the third wave involving the Eastern European revolutions that took place in the post-Cold War era. One of the unique elements is the use of information technology (IT) such as the Internet and other new social media which have highly characterized both revolutions.

As claimed by Noha Bakr, social electronic media like AlJazeera, BBC and CNN have clearly played a crucial part. The influence of organizing and communicating via Twitter, Facebook, Blogs also YouTube's viewing emphasizes a new technique in mass mobilization as well as the formation of a revolution [8]. For example, as Noha Bakr demonstrates, in Egypt, between $11^{\text {th }}$ January and $10^{\text {th }}$ February 2011, there were 34 million participants in the revolution on Facebook across 2313 pages, and 93 million Tweets on the revolution were exchanged within Egypt internally and externally. Looking back at the previous wave of democratization, the absence and non-existence of this current technology at that time forced the idea of democratic transition to penetrate from the 'underground' by established groups and political parties. Unlike the Arab Spring which lasted for several weeks, for each country, the previous wave of democratization took nearly several years for the regime change to take place via mass uprisings. The most remarkable elements in the Arab Spring by no doubt were its rapid progress and spontaneity.

Apart from that, the Tunisian and Egyptian Revolutions, as pointed out by Howard and Hussain are historically unique because they were the first set of political upheavals in which all important aspects were digitally mediated [9]. Digital media particularly the new social media have undoubtedly changed the tactics for democratization movements. The existence of tech-savvy civil society groups in Tunisia and Egypt managed to remove their dictators with few casualties compared to the American Revolution and France Revolution in the first wave, as well as in the second and third waves of democratization.

Furthermore, the new social media had a causal role in the Arab Spring in general and in the Tunisian and Egyptian Revolutions in particular as it provided the very infrastructure that created strong communication ties before 
the mass protests broke out and while street demonstrations were being formalized [10]. In each case of the Jasmine and 25 January revolution, the inciting incidents were digitally mediated in some way and information infrastructure, in the form of new social media had well inspired people to protest against dictatorship and social injustice [11].

\section{Summary- The ARAB Spring: A Product OF THIRD WAVE OR FOURTH WAVE OF DEMOCRATIZATION?}

With reference to the concept of democracy waves as set out by Huntington, in which he identifies three waves of democratization in the world political history, there is a range of opinions to determine the future democratic wave post-cold war era. Kenan Agin argues that the Arab Spring should be the fifth wave of democracy as he emphasized the evident features which are qualitatively similar to the third wave of democracy in Latin America in the 70s [12]. Meanwhile, Ali Sarihan indicates that the Egyptian revolution has experienced all of Huntington's third wave democratic phases and therefore meets the standards of the third wave of democratization [13]. Additionally, Olimat has found his own argument about the fourth wave of democratization in the Arab world when he claims that the tragic events of September 11 provided the impetus for democratic opportunity in the region [14]. Under this wave, he demonstrates that democratization is a matter of security, necessity and moral imperative.

Essentially, this article tends to argue in a different way from the above opinions. Despite sharing the common factors which is economic development and political legitimacy which led to the democratic transition in the previous wave, the Arab Spring has its own unique factorsthe role of new social media which impressively contributes to the success of regime change in Egypt and Tunisia. As Seib points out, the community of the new social mediawhich expands through new technology, will be among the most important players in determining whether conflict or peace prevails, which will in turn affect the chances for the expansion of democracy in the 21 st century [15]. The new wave of democratization is aligned with media effects, accelerates the process and is pushed along in part by transforming the state such as the Tunisian and Egyptian Revolutions. It seems fair enough to acknowledge what the former managing director of AlJazeera, Mohammed Jasim has said:

\section{"Democracy is coming to the Middle East because of the communication revolution. You can no longer hide information and must tell the people the truth. If you don't, the people won't follow you, they won't support you, they won't obey you" [16].}

Therefore, this article strongly argues that it is not an exaggeration to see the Arab Spring, which highlights the role of new social media manifested through Tunisian and
Egyptian Revolutions, as the one that started the new wave or the fourth wave of democratization, that had begun in the late 2010 and is still ongoing throughout the Middle East and North Africa regions.

\section{ACKNOWLEDGMENT}

This research was financially supported by the University Special Research Grant - Perception and Influence of Arab Spring among the Malay Society in Malaysia (GUP-2013-050), The National University of Malaysia.

\section{REFERENCES}

[1] Eva Bellin. Lessons from the jasmine and nile revolutions: possibilities of political transformation in the Middle East? Middle East Brief, vol. 50, pp. 2-7, 2011.

[2] Samuel Huntington. The Third Wave: Democratization in the Late Twentieth Century. University of Oklahoma Press, Oklahoma, 1991.

[3] S.M. Lipset. Some social requisites of democracy: economic development and political legitimacy. American Political Science Review, vol. 53 (March), pp. 69-105, 1959.

[4] D.A. Rustow. Transitions to democracy: toward a dynamic model, Comparative Politics, vol. 3, pp. 337-363, 1970.

[5] P.N. Howard and M.M. Hussain, Democracy's Fourth Wave? Digital Media and the Arab Spring. Oxford University Press, Oxford, 2013.

[6] Alfred Stepan, Tunisia's transition and the twin tolerations, Journal of Democracy, vol. 23 (2), pp. 89-102, 2012.

[7] Eva Bellin. Lessons from the jasmine and Nile revolutions: possibilities of political transformation in the Middle East? Middle East Brief, vol. 50, pp. 2-7, 2011.

[8] Noha Bakr, The Egyptian Revolution, 2012 (http://www.um.edu.mt/data/ assets/pdffile/0004/150394/Chapter4Noha_Bakr.pdf ).

[9] P.N. Howard and M.M. Hussain, Democracy's Fourth Wave? Digital Media and the Arab Spring. Oxford University Press, Oxford, 2013.

[10]P.N. Howard and M.M. Hussain, Democracy's Fourth Wave? Digital Media and the Arab Spring. Oxford University Press, Oxford, 2013.

[11]P.N. Howard and M.M. Hussain, Democracy's Fourth Wave? Digital Media and the Arab Spring. Oxford University Press, Oxford, 2013.

[12]Kenan Engin, The Arab Spring: The 5.0 Democracy Wave. Daily News, 2011.

[13]Ali Sarihan, Is the Arab spring in the third wave of democratization? The case of Syria and Egypt, Turkish Journal of Politics, vol.3 (1), pp. 67-83, 2012.

[14]Muhammad Olimat. The fourth wave of democratization, The American Journal of Islamic Social Sciences, vol. 25 (2), pp. 16-42, 2008.

[15]Philip Seib, New Media and the New Middle East, Palgrave Macmillan, Hampshire, 2007.

[16]Philip Seib, New Media and the New Middle East, Palgrave Macmillan, Hampshire, 2007. 